\title{
Do Inclusive Education Policies Improve Employment Opportunities? Evidence from a Field Experiment
}

Documento de discusión CIUP DD2001 December 2020

Jorge M. Agüero University of Connecticut jorge.aguero@uconn.edu

Francisco B. Galarza Universidad del Pacífico galarza_fb@up.edu.pe

Gustavo Yamada Universidad del Pacífico yamada_ga@up.edu.pe

\section{CENTRO DE INVESTIGACIÓN


Las opiniones expresadas en este documento son de exclusiva responsabilidad de los autores y no expresan necesariamente aquellas del Centro de Investigación de la Universidad del Pacífico o de la Universidad misma.

The opinions hereby expressed are those of the authors and are not necessarily in agreement with the Universidad del Pacifico's views or its Research Center's. 


\title{
DO INCLUSIVE EDUCATION POLICIES IMPROVE EMPLOYMENT OPPORTUNITIES? EVIDENCE FROM A FIELD EXPERIMENT ${ }^{1}$
}

\author{
Jorge M. Agüero \\ Universidad del Pacífico \\ Francisco B. Galarza \\ Universidad del Pacífico \\ Gustavo Yamada \\ Universidad del Pacífico
}

December 2020

\begin{abstract}
In labor markets where disadvantaged students are discriminated against, merit-based college scholarships targeting these students could convey two opposing signals to employers. There is a positive signal reflecting the candidate's cognitive ability (talented in high-school and able to maintain a high GPA in college) as well as her soft skills (overcoming poverty). There is also a possible negative signal as the targeting of the scholarship indicates that the beneficiary comes from a disadvantaged household. We conduct a correspondence study to analyze the labor market impact of an inclusive education program. Beca 18 provides merit-based scholarships to talented poor students admitted to 3-year and 5-year colleges in Peru. We find that the positive signal dominates. Including information of being a scholarship recipient increases the likelihood of getting a callback for a job interview by $20 \%$. However, the effect is much smaller in jobs and careers where the poor are under-represented, suggesting that the negative signal of the scholarship is not zero.
\end{abstract}

Key words: Employment, inclusive education, correspondence study, discrimination.

JEL Codes: C93, I23, J7, J15.

1 Agüero: University of Connecticut, Department of Economics and El Instituto (jorge.aguero@uconn.edu); Galarza: Universidad del Pacífico, Department of Economics (galarza_fb@up.edu.pe); Yamada: Universidad del Pacífico, Department of Economics (yamada_ga@up.edu.pe). Mayda Cama, Alejandra Jara, David Mata, Marco Ríos-Luna, Aeton Salas, Fernando Chu, Gabriela Rodriguez and Mary Vlamis provided excellent research assistance. We also thank comments from seminars participants at the University of Wisconsin, Madison, Universidad de Piura and Universidad del Pacífico, NIP-Uruguay, NEUDC, Southern Economic Association and University of Passau. We thank the financial support from UConn's El Instituto and Pronabec. This study was approved by University of Connecticut's IRB (H18-256) and is registered at the AEA RCT Registry https://doi.org/10.1257/rct.3842-1.2000000000000002. All errors are our responsibility. 


\section{Introduction}

Worldwide, students from disadvantaged backgrounds are largely under-represented in higher education (UNESCO, 2020; Ferreyra et al., 2017), despite the documented high skill earnings premium (Patrinos and Psacharopoulos, 2020; Goldin and Katz, 2008). This is more salient in developing countries, where returns to postsecondary education are higher and credit constraints are more pronounced than in advanced economies. New work has started to emerge on the role of financial aid and student loan programs on access to college for high-achieving low-income students in middle-income countries (e.g., Londoño-Vélez et al., 2020; Solis, 2017). ${ }^{2}$ Yet, little is known about the labor market returns of these merit-based scholarships.

To address this gap, we study the labor market impact of a scholarship for talented but disadvantaged students in Peru. This program, called Beca 18 ("Scholarship 18"), was created in 2011, and is the largest public program financing higher education in the country. Beca 18 is a highly competitive scholarship. Only five percent of applicants receive it every year. It is also a very generous scholarship to attend selected public or private colleges in the country. It covers full tuition costs plus all living expenses, books, moving costs, a laptop, health insurance and academic tutors, if needed. To satisfy its mandate to reduce the socioeconomic gap in access to higher education in Peru, Beca 18 targets students from the bottom two quintiles of the country's poverty assessment, in which indigenous groups are severely over-represented.

However, in labor markets where indigenous groups are discriminated against as in the case of Peru (e.g., Galarza and Yamada, 2014, 2017), a merit-based scholarship for disadvantaged students could convey two possible signals to employers. First, there is a positive signal in terms of ability. A Beca 18 beneficiary had to be a top student in high school to become eligible and to score very well in a qualifying standardized test and be admitted to a selective college to be awarded the scholarship. She had to maintain a high GPA during college as well. All these sends a signal of strong cognitive skills. Beneficiaries also had to overcome poverty, showing resilience as well as important "soft" skills. Second, there is a negative signal due to poverty and ethnicity. The targeting of the scholarship clearly indicates that the recipient comes from a disadvantaged household, which correlates with a lower social status and indigenous background. Thus, the impact of Beca 18 to employers would depend on how the market values these two competing signals. If the ability signal is larger than the poverty signal, Beca 18 will have a positive impact on employment. Otherwise, it would hurt candidates.

If beneficiaries perceive that the poverty signal dominates, they will avoid listing Beca 18 in their resumes. We found evidence supporting this view. From a sample of resumes from actual beneficiaries, less than $5 \%$ listed the scholarship. Those who did it, place it as the last item in their resumes and without highlighting it. However, not including this award in their resume could be an inefficient behavior if employers value the ability signal much more than the poverty signal. Thus, we need to test how the labor market reacts to the Beca 18 signal.

We implement a correspondence audit study to examine the impact of Beca 18 on employment opportunities for technical (for 3-year college graduates) and professional occupations (5-year college graduates). ${ }^{3}$ Nearly 3500 fictitious resumes were sent in response to 877 job ads in Lima, Peru's capital and largest labor market (concentrating $44 \%$ of the country's labor force). For each job we sent four resumes, randomly assigning all elements of the resumes, including the listing of Beca 18. These resumes mimicked those from true beneficiaries of Beca 18 in terms of style and structure, except that we make the information about the scholarship salient. We find that listing Beca 18 in the resume increases the likelihood to be called back for a job interview by $20 \%$.

2 For research on these programs in advanced economies see for example Angrist et al. (2014), Bettinger et al. (2019), Fack and Grenet (2015).

3 As explained below, Peru's high school education ends in grade 11 (not 12) and the higher education system has 3-year (technical) and 5-year (professional) colleges. 
This finding implies that the ability signal exceeds the poverty signal. Beneficiaries of Beca 18 are leaving "money on the table" by not listing the scholarship in their resumes.

To understand better the role of each signal, we conducted a heterogeneity analysis dividing the sample by jobs, careers and place of residence. The intuition is that the negative signal from poverty will be less (more) salient in the subgroups where the poor are (under-) over-represented. We find evidence supporting this prediction. For example, we show that gains from listing Beca 18 in the resume is concentrated among 3-year college graduates, where the poor are more likely to graduate from. The gains in callback rates increases to $39 \%$ in this subsample. For graduates from 5 -year colleges, where the poor are under-represented, the effect is just $6 \%$ and not statistically different from zero. These findings suggest that the negative signal is not zero when the poor are underrepresented.

One potentially additional impact of Beca 18 is the reduction of ethnic gaps, not only in terms of college enrollment and graduation rates, but also in labor market outcomes, a topic over which the literature is particularly scarce. Using surnames as an ethnic signal, we find that the return to Beca 18 is the largest among job applicants with paternal and maternal indigenous surnames, a result suggesting a greater ethnic equality in the access to the labor market.

We contribute to two strands of the literature. First, the literature on the impact of financial aid and loan programs for higher education has largely focused on enrollment (see, e.g., Angrist et al. 2014; Bettinger et al. 2019, and Fack and Grenet 2015, for developed countries, and Londoño-Velez et al., 2020; Laajaj et al., 2018 and Solis, 2017, for developing countries). We contribute to this area of study, by examining how the labor market responds to a merit-based and need-based scholarship program. That is, we extend the analysis of the impact of these type of programs beyond college graduation, a topic over which the literature in developing countries is particularly scant.

Second, the fast-growing literature on correspondence studies (CS) has been widely used to detect ethnic and gender discrimination in the labor market, both in developed and developing countries (see Neumark, 2018 and Baert, 2018 for recent reviews). While their results are revealing, it is unclear from existing CS which policy prescription to use to increase employment opportunities for disadvantaged groups. This is particularly relevant since anonymous job applications do not seem to help as much, as Behaghel et al. (2015) shows for France. We evaluate the effect of an inclusive education policy on higher access to the labor market, as an alternative to using anonymous resumes. We posit that, while an affirmative action policy could reinforce discrimination (Coates and Loury, 1993), sending a signal of ability could address, at least partly, the issue, depending on how the poverty and ability signals are perceived in the labor market. ${ }^{4}$ We are not aware of other CS examining this labor market effect of similar programs.

The remainder of the paper proceeds as follows. Section 2 provides information about the Beca 18 program (coverage, requirements, and outreach). Section 3 presents our experimental design. Section 4 introduces our data. Section 5 discusses our results and section 6 concludes.

4 We focus on hiring because this program is too young as to analyze other labor market outcomes, such as its impact on wages. This extension to analyze the human capital impact of the program is an important topic for future research. 


\section{Beca 18 program}

Created in late 2011, Beca 18 began to operate the following year as the first full scholarship program for higher education funded by the national government in Peru. ${ }^{5}$ With the aim to reduce the poor's unequal access to higher education, Beca 18 funds full tuition and related expenses of young talented students coming from poor households who have been admitted to selective private and public universities (5-year college degrees) and technical institutions (3-year college degrees). Beca 18 granted 65.826 scholarships from 2012 to 2019, with some changes in administrative issues of the application but keeping its focus on talented students from disadvantaged backgrounds. About two thirds of the scholarships were granted to fund 3-year technical degrees.

All Peruvian nationals attending-or graduated from-a public high school, interested in applying for a scholarship need to pass a pre-selection process, summarized in Appendix Figure 1. The eligibility criteria is based on age (under 22), household poverty condition (verified by SISFOH, the national system of household targeting for social programs), and academic merit (top third in GPA in the last two years prior to their application). ${ }^{6}$ In addition, Beca 18 pre-candidates must take a national test of math and reading comprehension, in order to qualify for the final round. The final ranking considers test scores plus some bonus points awarded to applicants in priority situations including indigenous groups. ${ }^{7}$ As shown in Appendix Figure 1, using numbers from the 2019 process, only about one tenth of applicants $(4,539$ out of 43,906$)$ made it to this stage, given the budget constraint of the program. An additional third of applicants were eliminated in the final round of the process, considering admission and quality of the colleges and careers chosen. ${ }^{8}$ Only 3,139 scholarships were ultimately granted that year, yielding a success rate of $5.19 \%$.

Beca 18 covers full tuition costs of attending a public or private 3-year or 5-year colleges. It also covers course materials, tuition to study English (only for 5-year colleges), academic tutoring, and a laptop, in addition to health insurance, living expenses (food, housing), local transportation, and a round-trip ticket to the place of residence, if applicable. ${ }^{9}$

Merit-based higher education scholarships targeting to the poor are also available in other Latin American countries, such as Brazil, Chile, Colombia, and Costa Rica, though we are not aware of studies of the effect of those scholarship programs on labor market access. Table 1 summarizes the characteristics of relatively large public programs for higher education scholarships in the region. With 84.8 U.S. million dollars of budget spent in 2019, Beca 18 ranks first in terms of relative fiscal effort devoted to finance the program $(0.27 \%$ of central government budget), though it is the smallest program in the sample, both, in terms of absolute numbers of beneficiaries (15.619 in 2019) and relative to total enrollment in higher education $(0.87 \%)$.

5 Prior to Beca 18, PRONABEC, the Ministry of Education office in charge of administering the program, had only had short-term loans financing tuition expenses for less than a year.

6 Students can apply during their senior year (11th grade) but also after high school graduation as long as they are younger than 22.

7 Other criteria rising eligibility are disability, active firefighter (or children of firefighter), volunteers registered by the Ministry of Women and Vulnerable Populations, farmers, and Afro-descendant population.

8 Quality indicators include the college ranking (which is based on scientific production, faculty with undergraduate or graduate degrees, and instructor/student ratio), graduation rates, and average wages of graduates. All these indicators are used to construct a list of prioritized colleges, whose ranking is used to award the bonus points for college quality. In terms of careers, bonus points are awarded in direct relationship to their economic returns, and to whether those careers belong to areas of science and technology prioritized in the 2006-2021 National Strategic Plan of Science, Technology, and Innovation for the Competitiveness and Human Development (life sciences, biotechnology, material technology and science, information and communication technologies, environmental science, and basic sciences-mathematics, chemistry physics, biology, geology, and geophysics).

9 A significant proportion of the scholarship recipients are born in a rural place and choose to migrate and study in a college located in Lima. As of 2016, only $13 \%$ of the recipients reside in Lima but $53 \%$ of all recipients chose to attend a college in Lima. 
Table 1: A Sample of Government-Funded Higher Education Scholarship Programs in Latin America

\begin{tabular}{|c|c|c|c|c|c|c|}
\hline Program & Country & General Qualification Requirements & $\begin{array}{c}\text { Number of } \\
\text { Beneficiaries } \\
\text { (Latest Year } \\
\text { Available) }\end{array}$ & $\begin{array}{l}\text { Number of } \\
\text { Beneficiaries } \\
\text { / Total Higher } \\
\text { Education } \\
\text { Students (\%) }\end{array}$ & $\begin{array}{c}\text { Annual } \\
\text { Government } \\
\text { Expenditure on } \\
\text { the Program } \\
\text { (millions of U.S. } \\
\text { dollars) }\end{array}$ & $\begin{array}{l}\text { Program } \\
\text { Expenditure } \\
\text { /Central } \\
\text { Government } \\
\text { Expenditure } \\
\text { (\%) }\end{array}$ \\
\hline ProUni & Brazil & $\begin{array}{l}\text { 1) Gross family income of up to } 3 \text { minimum wages. } \\
\text { 2) Minimum score in the Exame Nacional do } \\
\text { Ensino Médio. }\end{array}$ & 224,921 (2019) & 2.66 & 549.4 & $0.09^{\mathrm{b}}$ \\
\hline $\begin{array}{c}\text { Beca } \\
\text { Bicentenario }\end{array}$ & Chile & $\begin{array}{l}\text { 1) Belong to bottom } 70 \% \text { of household income } \\
\text { distribution. } \\
\text { 2) Minimum score in the University Selection Test. } \\
\text { 3) Be enrolled in an eligible institution and } \\
\text { educational field. }\end{array}$ & $34,755(2017)$ & 5.27 & 140.5 & 0.22 \\
\hline Ser Pilo Paga & Colombia & $\begin{array}{l}\text { 1) Be registered in the System of Selection of } \\
\text { Beneficiaries for Social Programs (SISBEN). } \\
\text { 2) Minimum score in the national test "Saber 11". } \\
\text { 3) Be admitted in an eligible institution. }\end{array}$ & $40,000^{c}(2018)$ & 1.79 & 253.9 & 0.04 \\
\hline $\begin{array}{c}\text { Beca } \\
\text { Universitaria }\end{array}$ & Costa Rica & $\begin{array}{l}\text { 1) Poverty or extreme poverty condition accredited } \\
\text { by SINIRUBE. } \\
\text { 2) High academic performance (last period grades). } \\
\text { 3) Be enrolled in an institution and in a career } \\
\text { recognized by CONESUP. }\end{array}$ & 4,522 (2019) & 2.17 & 5.9 & 0.15 \\
\hline Beca 18 & Peru & $\begin{array}{l}\text { 1) Poverty or extreme poverty condition accredited } \\
\text { by SISFOH. } \\
\text { 2) Top third in GPA in last two years of secondary } \\
\text { education and minimum score in the pre-selection } \\
\text { test. } \\
\text { 3) Be admitted in an eligible institution and } \\
\text { educational field. }\end{array}$ & 15,619 (2019) & 0.87 & 84.8 & 0.27 \\
\hline
\end{tabular}

Sources: Banco Central do Brasil, Ministério da Educação (Brazil), Ministério da Economia (Brazil), Banco Central de Chile, Ministerio de Educación (Chile), Consejo Nacional de Educación (Chile), Ministerio de Hacienda (Chile), Superintendencia Financiera de Colombia, Ministerio de Educación (Colombia), Ministerio de Hacienda y Crédito Público (Colombia), Banco Central de Costa Rica, FONABE, Programa Estado de la Nación (Costa Rica), Ministerio de Hacienda (Costa Rica), SBS, Ministerio de Economía y Finanzas (Peru), PRONABEC, SUNEDU, Ministerio de Educación (Peru), and World Bank (2019).

Notes:

a. In the case of Brazil, Costa Rica and Peru, the figures for total student population are of 2018, 2015 and 2016, respectively.

b. The central government expenditure figure is of 2018. In the first three quarters, spending in 2018 is similar to that of 2019.

c. Target number according to government announcements.

There are several potential effects that a scholarship program such as Beca 18 can have. In the short-term, it can increase higher education enrollment rates for ethnic minorities (indigenous and afro-descendants) and it may also increase graduation rates (thus increasing human capital accumulation). In the medium-term, the program may increase access to the labor market for poor people. And in the long run, it may ultimately reduce the ethnic income gap. We study the effect of Beca 18 on the increase in employment opportunities. As described before, we posit that being recipient of Beca 18 sends (at least) two signals to the market: the job applicant is talented (positive signal) but poor (negative signal). In this framework, the impact of Beca 18 on the labor market will depend on how employers read those signals: if the ability signal is stronger (weaker) than the poverty signal, Beca 18 will have a positive (negative) effect on hiring chances. 


\section{Experimental design}

We use a paired correspondence study design and sent four resumes in response to each selected job ad. We use the resume randomizer by Lahey and Beasley (2009), v.31, to construct all resumes, whose format and structure mirror those used by real Beca 18 recipients obtained thanks to PRONABEC. ${ }^{10}$ Two key variables for the experimental operation include the allocation of being recipient of Beca 18 and surnames, our major ethnic signal. Randomly assigned, two resumes indicated the job applicant had received Beca 18, while the remaining two did not. In terms of the surnames, each full name in the resume included a paternal and maternal surname, as is common in Peru.

As explained below in more detail, we have four equally likely combinations of paternal-maternal names by combining indigenous and mixed-race surnames: Indigenous-Indigenous (I-I), Mestizo-Indigenous (M-I), Indigenous-Mestizo (I-M), and Mestizo-Mestizo (M-M). In terms of gender, each resume had a 50\% chance of listing a woman's name, from a common pool regardless of the type of surnames. ${ }^{11}$ All selected jobs were either for technical (requiring a 3-year college degree) or professional (5-year degree) occupations. We did not select low-skilled occupations as we focus on college graduates.

\subsection{Beca 18 and education}

Half the resumes (per batch) sent to a job included the Beca 18 signal. We did this by assigning two possible wordings (randomly). The first wording said verbatim "Premios: Beca 18 (PRONABEC)" (Awards: Beca 18 (PRONABEC)). The second said "Beneficiario del Programa Nacional de Beca18 PRONABEC" (Beneficiary of the National Program Beca 18 - PRONABEC). We use the male variation for "becario" in all resumes. While not gender neutral, this is a common practice in Peru. The selected statement was listed right below the name of the college assigned to the resume. We used administrative data to select the 3-year colleges-called Institutos de Educación Superior, or Institutos, for short-and the 5-year colleges (called universidades). This selection, as well as that of the college majors, largely responded to the characteristics of the job vacancies posted. ${ }^{12}$ We further gathered information about whether the college and/or major was prioritized or not prioritized by the National Program of Scholarships and Education Loans (PRONABEC, for its acronym in Spanish), the public office from the Ministry of Education running the Beca 18 Program.

\subsection{Signaling indigenous status}

In Peru, as in many other Latin American countries, the use of two surnames (paternal and maternal, in that order) is widespread, for official identification purposes and also for job applications. In the latest population census, around a quarter of the population self-identifies as indigenous, with Quechua and Aimara being the largest groups among them. These groups have distinctive surnames and have been used in the literature before (e.g., Galarza and Yamada, 2014, 2017).

We used two ways to signal indigenous status: surnames and whether the job applicant went to a high school in a province outside of Lima, which is more likely to be populated by a larger share of indigenous people. In the case of surnames, an innovation of our experiment is that we can assess different degrees of our indigenous status on callbacks. In particular, we selected Indigenous (I) and mestizos (mixed race) (M) surnames and created four combinations of paternal - maternal surnames: M-M, M-I, I-M, and I-I (See Figure 2). We thus can compare the mestizo job

10 We did not include photographs in our resumes, which is not uncommon in Peru.

11 To our best knowledge, the performance of mestizos in labor access has not been analyzed elsewhere, with the only exception of Arceo-Gomez and Campos-Vasquez (2014) for Mexico.

12 The set of majors financed by Beca 18 is sufficiently broad as to not impose a constrain in the set of occupations matched with the job vacancies available every week. 
applicant (M-M) with an Indigenous job candidate of any of the three types (paternal only: I-M, maternal only: M-I, or both: I-I).

Our second signal is the high school graduation in an Indigenous/rural place (a province outside of Lima). Except for the M-M category, in the remaining three categories, each resume had a 2/3 chance of including the name of a high school located in a province, outside Lima. This signal may be considered a weaker signal of Indigenous status. To maximize our statistical power in the innovative aspect of our study, we sent four resumes for each job ad, each with one of the four combinations of surnames mentioned earlier.

Figure 2. Structure of the four resumes sent to a job ad

\begin{tabular}{|c|c|}
\hline $\begin{array}{l}\text { Resume } \\
\text { Mestizo } \\
\text { Address and contact information } \\
\text { Brief personal statement } \\
\text { College signal (Beca 18/No Beca 18) } \\
\text { High School signal (Lima) } \\
\text { Job } 1 \\
\text { Job 2 } \\
\text { Other skills }\end{array}$ & \begin{tabular}{|cc} 
B & \\
& Resume \\
& Indigenous (paternal only) \\
Address and contact information \\
Brief personal statement \\
College signal (Beca 18/No Beca 18) \\
High School signal (Lima/Province) \\
Job 1 \\
Job 2 2 \\
Other skills \\
\end{tabular} \\
\hline $\begin{array}{l}\text { Resume } \\
\text { Indigenous (maternal only) } \\
\text { Address and contact information } \\
\text { Brief personal statement } \\
\text { College signal (Beca 11/No Beca 18) } \\
\text { High School signal (Lima/Province) } \\
\text { Job 1 } \\
\text { Job } 2 \\
\text { Other skills }\end{array}$ & $\begin{array}{c}\text { Resume } \\
\text { Indigenous (paternal and maternal) } \\
\text { Address and contact information } \\
\text { Brief personal statement } \\
\text { College signal (Beca 18/No Beca 18) } \\
\text { High School signal (Lima/Province) } \\
\text { Job 1 } \\
\text { Job 2 } \\
\text { Other skills }\end{array}$ \\
\hline
\end{tabular}

The surnames used in this experiment come from a random sample drawn from the full list of surnames from real recipients of Beca 18. To construct the identities, we first classified the surnames of these recipients as Indigenous (I) and Mestizos (M) and, then, took a random sample without replacement of 400 surnames (200 I and $200 \mathrm{M}$ ), to construct 200 unique (and fictitious) combinations of paternal + maternal surnames, which are used in resumes. Sample surnames include Aylas, Ccori, Huasasquiche, Incahuamán, Mallqui, Ñahuin, Pomasoncco, Quispe, Rimaycuna, Sayritupac, Vilca, and Ynga, for Indigenous; and Alvarado, Baldeón, Castro, Delgado, Espejo, Fuentes, Hurtado, Mora, Porras, Segura, Valencia, and Zavala, for Mestizos. It is worth mentioning that we did not find any Anglo-Saxon surname in the administrative data of the program, so we decided to use only Indigenous and Mestizo surnames.

We validated our selection of surnames by conducting a survey with 82 freshmen undergraduate students. For each surname, they chose one of these three categories, Mestizo, Indigenous, or Other. Of our 100 Indigenous surnames, students considered them as such $85 \%$; and $76 \%$ for the 100 Mestizo surnames. Our validation rates are in line with the findings from Button and Walker (2020) for Native Americans in the United States.

\subsection{Age and given names}

The age of the job applicant, inferred from the year of graduation from high school, was set in the early 20s. We used common a pool of first and middle names (e.g., Juan, María), which were randomly assigned without replacement, using a common basis for each of the four groups created from the surnames. Then, for each of the four elements of a job applicant's full name ( 2 given names +2 surnames) the random assignment was without replacement. This allowed us to create 200 unique full names where no name appears more than once in any of the four elements (first name, middle name, paternal surname and maternal surname).

\subsection{Brief personal statements}

As common in Lima's labor market, every resume included a statement summarizing the profile of the job candidate in the form of a brief personal statement. They were randomly assigned, 
without replacement, from a set of eleven gender neutral statements.

\subsection{Residential addresses, e-mail addresses and telephone numbers}

We created a database with 200 addresses, which were assigned at random with no replacement, every time we constructed the four resumes for each selected job ad. Moreover, for each of the 200 identities, we created an email account, using one of the following four randomly chosen formats:

(i) PaternalSurname.GivenName

(ii) PaternalSurname.MaternalSurname.GivenName

(iii) PaternalSurname.MaternalSurname10.GivenName

(iv) PaternalSurname.MaternalSurname.GivenName10

Every set of four resumes sent to each job ad was randomly drawn from those choices. We used (four) unique cellphone numbers for each job applicant in response to a job ad. Each cellphone was assigned to one of our research assistants. Our assistants were instructed to answer phone calls and e-mails and register the information of the successful candidates. ${ }^{13}$ All invitations for an interview were promptly declined, to reduce the costs to the employers.

\subsection{Job history}

Job applicants have two entries for work experience in their resumes: past and current (all of them have been working during their last year in college), for a total of 2 to 3 years. These work experiences are specific to each job vacancy (we have at least 4 of them to be allocated to each entry), were adapted from real work experiences posted online for similar occupations and were randomly assigned to each job applicant.

\subsection{Other information}

English and Computing Skills: All resumes include a final section with information on the level of English and computing (Microsoft Office) proficiency. These levels were set at intermediate for the general case but were adjusted as requested by the job vacancy. All four job applicants for a given job ad, displayed the same level of proficiency, with the only change being the presentation format and wording. We further added any occupation-specific software requested in the job listing.

Formatting: Resumes vary independently and without replacement (when there are at least four choices) according to the four font types (e.g., Arial, Times New Roman), the alignment of the header with the name, residential address, email address and telephone (right, left, centered), heading of each section (e.g., education, work experience, other skills), heading format (in blue, in black, underlined, centered). Our database registers the type of format used for each resume sent.

13 Unlike other countries, setting up voice mails would not work in Peru, as callers almost never leave voice messages. WhatsApp messages are also extremely unusual as a way of contacting our job applicants. 


\section{Data}

\subsection{Sample size}

We sent 3,548 resumes between July 2019 and March 2020, ${ }^{14}$ in response to 887 job vacancies selected from help-wanted sections of newspapers in Lima, Peru. Power analysis suggested to send at least 2,210 resumes in order to detect a minimum effect of 0.07 , for an intra-conglomerate correlation of 0.1, a significance level of 0.05 and a power of 0.8. Correcting that figure for the loss of variance resulting from sending more than one resume for each job listing (as in Lahey and Beasly, 2018) yielded a sample size of 2,873 . Given that this power calculation uses as a reference studies for Peru that compare Whites with Indigenous, but we are comparing Mestizos with Indigenous (an effect more difficult to detect), our sample size required an additional upward adjustment.

\subsection{Occupations}

In terms of the occupations selected, we have a much broader types of jobs relative to most of the field experimental literature (as reviewed by Neumark, 2018 and Baertl, 2018). These are shown in Appendix Table 2 and largely responds to what the labor market demands. These occupations correspond to two types of jobs: technical (54\% of our sample) and professional jobs (46\%).

\subsection{Identifying job ads}

We identified potential job ads from the job listings published in two popular newspapers in Lima, El Trome and El Comercio, which print hundreds of ads from all economic activities. We did not restrict our selection to any particular occupational category. However, we excluded job ads that required in-person delivery of the resume or asked to include salary expectations in the resume. We also excluded ads for advanced managerial positions and rather focused on entry-level jobs, with up to three years of work experience, in almost all cases for a recent graduate. Appendix 3 shows a complete batch (four resumes) sent in response to a graphical design position.

\subsection{Emailing resumes}

Resumes were electronically sent between Monday afternoon and Thursday morning each week (with a few exceptions) using Thunderbird. We used its "Send later" extension to schedule the sending of emails at different times of the day. Copies of all incoming went to a master email account, to keep a record of each submission. We only sent resumes for one job listing per firm or employer. Every email sent in the batch of four had a different opening, body, and closing, to ensure that employers would not notice these job applications were related. Text in the email was short, standardized and gender neutral.

\subsection{Coding responses}

We coded responses as positive ("We are calling to set a job interview"), ambiguous ("Could you please send a copy of your ID") or negative ("Thanks for your application, but we have filled the position”). For the analysis in this paper, we consider only positive responses as callbacks.

\subsection{Balance tests}

Appendix Table 4 shows that the randomization of each element of the resumes was successful across treatment and control groups, that is, comparing resumes with and without the Beca 18 statements. Out of 371 variables, less than $2 \%$ of them ( 7 variables) are unbalanced at the $5 \%$ significance level. None remain unbalanced when accounting for multiple hypothesis testing using FDR-q adjustments of the p-values.

14 We had to stop the data collection due to the Covid-19 pandemic, when the Peruvian government declared a national lockdown. Part of our plan was to examine recruiters' hiring preferences, in order to better understand our empirical results. 


\section{Methodology}

We estimate the following equation, using Ordinary Least Squares (similar results are obtained using Probit models):

$$
\text { Callback }_{i j}=\beta_{0}+\beta_{1} \text { Beca } 18_{i j}+\beta_{C} \text { Controls }_{i j}+\alpha_{j}+\varepsilon_{i j^{\prime}}
$$

where Callback $_{i j}$ is equal to one if resume i received a callback in response to job ad $j$; Beca $18_{i j}$ equals 1, if the resume included a statement about being recipient of such scholarship; Controls is a vector of controls, for which we have three versions: (i) no controls; (ii) regular controls, which include controls at the individual level-sex, ethnicity (3 categories of surnames: Indigenous-Indigenous, Indigenous-Mestizo, and Mestizo-Indigenous, with Mestizo-Mestizo, as the base category), district of residence (to control for the socioeconomic status of the job applicant), type of occupation (technical or professional), whether the applicant graduated from a high school located in an indigenous location, or in Lima, and the phone number used in the job application-and job level-whether the major was prioritized and whether the college was prioritized ${ }^{15}$-in addition to the week the job was posted; and (iii) full controls (which adds controls at the resume level: format and style). We further include job ad fixed effects, $\alpha_{p}$ and correct the standard errors for clustering at the resume level in all specifications. 


\section{Results}

\subsection{Aggregate effect of Beca 18}

We first examine the mean (raw) callback rates by Beca 18 status, for each category of interest. As Table 3 shows, the callback rates for job applicants that indicated to be recipients of Beca 18 in their resumes are higher than for those who did not (the former receives $20 \%$ more callbacks than the latter). And this "Beca 18 effect" holds for all Indigenous categories considered (surnames and place of origin) and both genders, though the sample size for each category outlined below does not always allow to get statistical significance.

Table 3: Mean callbacks by ethnicity

\begin{tabular}{|c|c|c|c|c|c|}
\hline & $\mathbf{N}$ & Total & $\begin{array}{c}\text { Beca 18 } \\
\text { Non-Recipient }\end{array}$ & $\begin{array}{c}\text { Beca 18 } \\
\text { Recipient }\end{array}$ & Difference ( $p$-value) $)^{1 /}$ \\
\hline \multicolumn{6}{|l|}{ Indigenous Signals } \\
\hline \multicolumn{6}{|c|}{ A. Surnames (Paternal - Maternal) } \\
\hline Indigenous-Indigenous & 887 & 10.03 & 9.05 & 11.01 & 0.3310 \\
\hline Mestizo-Indigenous & 887 & 9.02 & 8.33 & 9.74 & 0.4633 \\
\hline Indigenous-Mestizo & 887 & 11.72 & 9.93 & 13.44 & 0.1048 \\
\hline Mestizo-Mestizo & 887 & 10.60 & 10.38 & 10.81 & 0.8363 \\
\hline \multicolumn{6}{|l|}{ B. Place of Origin } \\
\hline Rural High School & 1559 & 10.58 & 9.52 & 11.62 & 0.1781 \\
\hline Lima High School & 1989 & 10.16 & 9.33 & 11.00 & 0.2195 \\
\hline \multicolumn{6}{|l|}{ Gender } \\
\hline Female & 1798 & 11.96 & 11.27 & 12.65 & 0.3661 \\
\hline Male & 1750 & 8.68 & 7.48 & 9.87 & 0.0752 \\
\hline Total & 3548 & 10.34 & 9.41 & 11.27 & 0.0689 \\
\hline
\end{tabular}

${ }^{1 /}$ Two-sided test p-value.

The effects indicated above do not account for clustering nor do they control for the type of college, occupation, or district of residence. This is addressed in Table 4, which reports the Beca 18 estimates from Equation (1). The estimate with no controls (column 1) shows that a resume listing Beca 18 has a higher chance of receiving a callback for a job interview than a similarly-qualified resume not listing the scholarship. The Beca 18 premium is meaningful as it increases in $20 \%$ the callback ( $=0.019 / 0.094)$. Adding candidate controls (column 2 ), job controls (column 3), and indicator variables for the week the job was posted (column 4) confirms the 20\% difference in callbacks. The specification in column 4, which includes the regular controls, is our preferred one, and will be used in all remaining estimations. 
Table 4: Regression results on callbacks

\begin{tabular}{|c|c|c|c|c|c|}
\hline & (1) & (2) & (3) & (4) & (5) \\
\hline \multirow[t]{2}{*}{ Beca 18} & $0.019^{* *}$ & $0.019^{* *}$ & $0.019^{* *}$ & $0.019^{* *}$ & $0.020^{* * *}$ \\
\hline & $(0.007)$ & $(0.007)$ & $(0.007)$ & $(0.007)$ & $(0.007)$ \\
\hline Randomized Inference: $p$-value & {$[0.014]$} & [0.009] & {$[0.012]$} & {$[0.016]$} & {$[0.010]$} \\
\hline Candidate controls & No & Yes & Yes & Yes & Yes \\
\hline Job controls & No & No & Yes & Yes & Yes \\
\hline Week fixed effects & No & No & No & Yes & Yes \\
\hline Resume controls & No & No & No & No & Yes \\
\hline Adjusted $\mathrm{R}^{2}$ & 0.481 & 0.485 & 0.486 & 0.486 & 0.484 \\
\hline $\begin{array}{l}\text { Mean control (callback for Beca } 18 \\
\text { non-recipients) }\end{array}$ & 0.094 & 0.094 & 0.094 & 0.094 & 0.094 \\
\hline $\mathrm{N}$ & 3548 & 3548 & 3548 & 3548 & 3548 \\
\hline
\end{tabular}

Notes: Candidate controls include sex, ethnicity, district of residence, type of occupation; Job controls include indicators for prioritized major and college; Resume controls include several resume's format and style indicators (personal statements, headings style, font types, personal information style). All specifications include a constant term and job ad fixed effects. Robust standard errors (in parenthesis) are clustered at the resume level. P-values using randomized inference (with 1000 repetitions) in square brackets.

${ }^{*} \mathrm{p}<0.10,{ }^{* *} \mathrm{p}<0.05,{ }^{* * *} \mathrm{p}<0.01$.

Furthermore, our estimates are robust to the inclusion of full controls (column 5); in fact, doing so only increases the magnitude and significance of our estimate (yielding a $21 \%$ difference in callbacks). Additional robustness checks include the use of clustered standard errors at the job ad level, as in Lahey and Beasley (2009), Button and Walker (2020) and Beam et al. (2020), and applying randomized inference, as in Young (2019) and Imbens and Rubin (2015). Our main results are robust to those alternative estimations (see Appendix Table 5 for results with clustering at the job ad level, and row 3 in Table 4 for the randomized inference's p-values).

To put our Beca 18 coefficient estimate (20\%) in perspective, it is equivalent to $44 \%$ of the premium from graduating from the top six colleges in our sample (Pontifical Catholic University of PeruPUCP, National University of Engineering-UNI, Peruvian University Cayetano Heredia-UPCH, Southern Scientific University-UCSur, TECSUP, and the National Service of Training in Industrial Work-SENATI). ${ }^{16}$ An additional comparison of our estimate with a related study (Galarza and Yamada, 2017) indicates that it may help reduce the beauty gap in employment access by $25 \%$ and the racial gap by $37 \%$, though in that study the ethnic groups under scrutiny were Whites and Indigenous, both defined as having the paternal and maternal surnames from the referred category. All these findings indicate that the ability signal of Beca 18 dominates the negative poverty signal.

\subsection{Heterogenous effects}

To understand the relative role of the ability and poverty signal of Beca 18 we divide the sample in different groups according to where the poor are over- or under-represented. Our hypothesis is that the poverty signal will be larger in jobs, careers and for groups where the poor are under-represented. We start with splitting the sample by college type: 5-year vs. 3-year. There is a marked difference between universities (5-year colleges) and Institutos (3-year colleges), in terms of average tuition costs. With figures for 2015, the total average tuition cost of attending an Instituto in Lima was PEN 73.328 (equivalent to USD 21,500 at that time), PEN 162.883 for private universities, and PEN 80.759 for public universities (Apoyo, 2015). Specially comparing Institutos and private universities, this difference in tuition costs, may indicate a disparity in the socioeconomic status of the student population. This is further confirmed with data from representative household surveys. Students from low-socioeconomic status families are 2.8 times more likely to graduate from a 3-year college relative to a 5-year college. For students

16 Those colleges score within the top 10 universities and the top 5 Institutos, as of 2018 (SUNEDU, 2018). 
from high-socioeconomic status families the ratio is $0.25 .^{17}$ Thus, we expect the Beca 18 callback premium to be larger for candidates from 3-year colleges. This is shown and confirmed in Table 6.

Table 6 presents estimates from estimating equation (1) by type of college: for 3-year colleges (Institutos) and 5-year colleges (universities). Column 1 reports the estimate for all sample, for comparison. In column 2, when restricting the sample only to Institutos is there a significant effect: graduates from Institutos that received Beca 18 increase their chances to get a callback by $39.2 \%(=0.031 / 0.079)$ relative to those without a scholarship. In the case of universities, column 3 , though those graduates with a Beca 18 receive $6.2 \%$ more callbacks $(=0.007 / 0.112)$ than those without such scholarship, the coefficient is not statistically significant. This result suggests different dynamics within each segment of the labor market, with the ability signal prevailing over the poverty signal in the case of Institutos.

Table 6: Effects by college type: 3-year and 5-year

\begin{tabular}{|c|c|c|c|}
\hline & (1) & $\begin{array}{c}(2) \\
\text { 3-year college }\end{array}$ & $\begin{array}{c}(3) \\
5 \text {-year college }\end{array}$ \\
\hline \multirow[t]{2}{*}{ Beca 18} & $0.019^{* *}$ & $0.031^{* * *}$ & 0.007 \\
\hline & $(0.007)$ & $(0.010)$ & $(0.011)$ \\
\hline Randomized Inference: p-value & {$[0.016]$} & [0.002] & [0.539] \\
\hline Adjusted $\mathrm{R}^{2}$ & 0.486 & 0.410 & 0.561 \\
\hline Regular controls & Yes & Yes & Yes \\
\hline Mean control (callback for Beca 18 non-recipients) & 0.094 & 0.079 & 0.112 \\
\hline $\mathrm{N}$ & 3548 & 1903 & 1645 \\
\hline
\end{tabular}

Note: All specifications include a constant term and job ad fixed effects. All specifications include a constant term and job ad fixed effects. Robust standard errors (in parenthesis) are clustered at the resume level. P-values using randomized inference (with 1000 repetitions) in square brackets.

${ }^{*} \mathrm{p}<0.10,{ }^{* *} \mathrm{p}<0.05,{ }^{* * *} \mathrm{p}<0.01$.

PRONABEC, the Peruvian government office administering the Beca 18 program, has a list of prioritized colleges and careers that is used at every scholarship call. The criteria used for this prioritization are broadly based on quality indicators (see notes to Appendix Figure 1, for details). Yet, the poor are under-represented in these colleges and careers. Table 7 reports the estimates breaking the sample by these categories. As seen below, the effect of Beca 18 for non-prioritized colleges is $58.5 \%$, while that for prioritized colleges is $20.0 \%$. This result is consistent with our prior findings.

Table 7: Effects by college type: prioritized and non-prioritized

\begin{tabular}{|c|c|c|c|}
\hline & $\begin{array}{l}\text { (1) } \\
\text { All }\end{array}$ & $\begin{array}{c}\text { (2) } \\
\text { Prioritized }\end{array}$ & $\begin{array}{c}(3) \\
\text { Non-prioritized }\end{array}$ \\
\hline \multirow[t]{2}{*}{ Beca 18} & $0.019^{* *}$ & $0.018^{* *}$ & $0.072^{* *}$ \\
\hline & $(0.007)$ & $(0.008)$ & $(0.036)$ \\
\hline Randomized Inference: p-value & {$[0.016]$} & [0.030] & [0.023] \\
\hline Regular controls & Yes & Yes & Yes \\
\hline Adjusted $\mathrm{R}^{2}$ & 0.486 & 0.483 & 0.558 \\
\hline Mean control (callback for Beca 18 non-recipients) & 0.094 & 0.090 & 0.123 \\
\hline $\mathrm{N}$ & 3548 & 3114 & 434 \\
\hline
\end{tabular}

Note: All specifications include a constant term and job ad fixed effects. All specifications include a constant term and job ad fixed effects. Robust standard errors (in parenthesis) are clustered at the resume level. P-values using randomized inference (with 1000 repetitions) in square brackets.

${ }^{*} \mathrm{p}<0.10,{ }^{* *} \mathrm{p}<0.05,{ }^{* * *} \mathrm{p}<0.01$.

17 We use data from the Peruvian National Household Survey (ENAHO, for its acronym in Spanish), which provides socioeconomic information, representative at the region level. We pooled the surveys from 2009 to 2019 , for the population between ages 22-35, with some college education (complete or not), but no longer enrolled in college (dropouts or graduates). We further restricted the sample to those living with their parents (for ages 22-25, roughly 70\% of them lived with at least one parent). The reported figures correspond to Metropolitan Lima. Low (high) socioeconomic status refers to the lowest (highest) quintile of parents' schooling, since schooling is highly correlated with poverty. 
In Table 8 we split the sample by the district of residence (in Lima city) assigned to the resume. Using the 2017 Poverty Map at the district level (INEI, 2019), we classify districts as poor (below the median) and affluent (above the median). Again, we continue to see a larger callback premium when the candidate resides in the randomly assigned poorer districts. A much smaller callback premium and not statistically significant is observed in the affluent districts. In Appendix Table 9 we further divide the sample by this poverty level and by type of college. We find that the bulk of the effects come from job candidates from poorer districts who graduated from 3-year colleges. Overall, these results validate the hypothesis that the callback premium for Beca 18 is larger for candidates where the poor are over-represented. This suggests that the negative signal of the scholarship is not zero. ${ }^{18}$

Table 8. Effects by place of residence

\begin{tabular}{|c|c|c|c|}
\hline & $\begin{array}{l}\text { (1) } \\
\text { All }\end{array}$ & $\stackrel{(2)}{\text { Poorer districts }}$ & $\begin{array}{c}\text { (3) } \\
\text { Affluent districts }\end{array}$ \\
\hline \multirow[t]{2}{*}{ Beca 18} & $0.019^{* *}$ & $0.028^{* * *}$ & 0.010 \\
\hline & $(0.007)$ & $(0.010)$ & $(0.022)$ \\
\hline Randomized Inference: p-value & {$[0.016]$} & [0.004] & {$[0.586]$} \\
\hline Regular controls & Yes & Yes & Yes \\
\hline Adjusted $\mathrm{R}^{2}$ & 0.486 & 0.515 & 0.424 \\
\hline Mean control (callback for Beca 18 non-recipients) & 0.094 & 0.086 & 0.110 \\
\hline $\mathrm{N}$ & 3548 & 2320 & 1228 \\
\hline
\end{tabular}

Note: All specifications include a constant term and job ad fixed effects.

Robust standard errors (in parenthesis) are clustered at the resume level. P-values using randomized inference (with 1000 repetitions) in square brackets.

${ }^{*} \mathrm{p}<0.10,{ }^{* *} \mathrm{p}<0.05,{ }^{* * *} \mathrm{p}<0.01$

Beca 18 targets students from poor families. And poverty and ethnicity are correlated in Peru, with Indigenous being among the poorest of the poor. To examine whether the return to Beca 18 differs by surname type, we add an interaction term to equation (1):

$$
\begin{aligned}
\text { Callback }_{i j}= & \beta_{0}+\beta_{1} \text { Beca } 18_{i j}+\beta_{S} \text { Surname Type }_{i j}+\beta_{S B} \text { Surname } \\
& \text { Type }_{i j}^{*} \text { Beca } 18_{i j}+\beta_{C} \text { Controls }_{i j}+\alpha_{j}+\varepsilon_{i j^{\prime}}
\end{aligned}
$$

where: Surname Type is a vector that includes three categories (Indigenous - Indigenous, Indigenous - Mestizo, and Mestizo - Indigenous). From this equation, estimated for all sample, 3-year and 5-year colleges, we recover the estimates of interest, reported in Table 11. Those returns are relative to the average callback on non-recipients of Beca 18. Considering column 1, we see that job applicants, recipients of Beca 18, with paternal and maternal Indigenous surnames receive $37.7 \%$ more callbacks than applicants without Beca 18 . This aggregate effect comes from the returns received by graduates from Institutos, where such return is $66.5 \%$ (column 2). Further note that the point estimate for Indigenous-Indigenous surnames is the highest among the four surname types, for the entire sample and each type of college, a result that suggests Beca 18 could help reduce ethnic gaps in access to employment opportunities, at least for 3-year colleges. 
Table 11. Returns to Beca 18 by surname type

\begin{tabular}{|c|c|c|c|}
\hline $\begin{array}{l}\text { Paternal - Maternal } \\
\text { Surnames }\end{array}$ & $\begin{array}{l}\text { (1) } \\
\text { All }\end{array}$ & $\begin{array}{c}\text { (2) } \\
\text { 3-year college }\end{array}$ & $\begin{array}{c}(3) \\
5 \text {-year college }\end{array}$ \\
\hline \multirow[t]{2}{*}{ Indigenous - Indigenous } & $0.377^{* *}$ & $0.665^{\text {** }}$ & 0.226 \\
\hline & $(0.179)$ & $(0.301)$ & $(0.219)$ \\
\hline \multirow[t]{2}{*}{ Indigenous - Mestizo } & 0.022 & -0.200 & 0.177 \\
\hline & $(0.189)$ & $(0.314)$ & $(0.231)$ \\
\hline \multirow[t]{2}{*}{ Mestizo - Indigenous } & 0.129 & $0.540^{*}$ & -0.166 \\
\hline & $(0.184)$ & $(0.307)$ & $(0.224)$ \\
\hline \multirow[t]{2}{*}{ Mestizo - Mestizo } & 0.258 & $0.558^{*}$ & 0.019 \\
\hline & $(0.183)$ & $(0.310)$ & $(0.219)$ \\
\hline Adjusted R2 & 0.485 & 0.411 & 0.560 \\
\hline Mean control (callback for Beca 18 non-recipients) & 0.094 & 0.079 & 0.112 \\
\hline $\mathrm{N}$ & 3548 & 1903 & 1645 \\
\hline
\end{tabular}

Note: All specifications include a constant term and job ad fixed effects.

Robust standard errors (in parenthesis) are clustered at the resume level.

${ }^{*} \mathrm{p}<0.10,{ }^{* *} \mathrm{p}<0.05,{ }^{* * *} \mathrm{p}<0.01$ 


\section{Conclusion}

Students from poor families in developing countries are largely under-represented in higher education. And Peru is not an exception: while there is almost no difference in access to primary education by household income levels, there is a 15 percentage points gap in access to secondary education between the richest quintile and the poorest quintile, and this gap increases to 44 percentage points in the case of higher education. One of the policies implemented by the governments in developing countries to reduce such inequality has been the creation of financial aid and student loan programs. We evaluate the effect of the need-based and merit-based Beca 18 program, which grants scholarships to attend 3-year and 5-year colleges in Peru. We find a significant effect of Beca 18 on employment opportunities for poor, talented students. This suggests that the ability signal dominates the poverty signal. Large callback premiums among the poor suggest that the poverty signal is not zero. We further observe that the Beca 18 effect is the largest for job applicants with both paternal and maternal Indigenous surnames. Taking our results in perspective, scaling-up this merit-based scholarship program would allow to reduce not only the socioeconomic gaps in college enrollment, but also the income ethnic gaps among college graduates (a result to which our paper relates). 


\section{References}

Angrist, Joshua, Autor, David, Hudson, Sally, Pallais, Amanda (2014). "Leveling Up: Early Results from a Randomized Evaluation of Post-Secondary Aid.” NBER Working Paper 20800.

Apoyo Consultoría (2015). "Evaluación de diseño y ejecución de presupuesto del Programa Nacional Beca 18”. Final Report.

Arceo-Gomez, Eva O., Campos-Vazquez, Raymundo M. (2014). "Race and Marriage in the Labor Market: A Discrimination Correspondence Study in a Developing Country," American Economic Review, Papers \& Proceedings, 104(5): 376-380.

Beam, Emily A., Hyman, Joshua, Theoharides, Caroline (2020), "The Relative Returns to Education, Experience, and Attractiveness for Young Workers," Economic Development and Cultural Change, 68(2): 391-428.

Baert, Stijn (2018). "Hiring discrimination: An overview of (almost) all correspondence experiments since 2005”. In S. Michael Gaddis (Ed.), Audit studies: Behind the scenes with theory, method, and nuance. Cham: Springer International Publishing.

Behaghel, Luc, Crépon, Bruno, Le Barbanchon, Thomas (2015). "Unintended Effects of Anonymous Résumés.” American Economic Journal: Applied Economics 7(3): 1-27.

Bettinger, Eric, Gurantz, Oded, Kawano, Laura, Sacerdote, Bruce, Stevens, Michael (2019). "The Long Run Impacts of Merit Aid: Evidence from California’s Cal Grant.” American Economic Journal: Economic Policy 11 (1): 64-94.

Button, Patrick, Walker, Brigham (2020). "Employment Discrimination against Indigenous Peoples in the United States: Evidence from a Field Experiment," Labour Economics, 65. August.

Coate, S. and Loury, G.C. (1993). "Will affirmative-action policies eliminate negative stereotypes?." The American Economic Review 83(5):1220-1240.

Ferreyra, María, Avitabile, Ciro, Botero, Javier, Haimovich, Francisco, Urzúa, Sergio (2017). At a Crossroads. Higher Education in Latin America and the Caribbean. Washington, DC: The World Bank.

Fack, Gabrielle, Grenet, Julien (2015). "Improving College Access and Success for Low-Income Students: Evidence from a Large Need-Based Grant Program.” American Economic Journal: Applied Economics 7 (2): 1-34.

Galarza, Francisco, Yamada, Gustavo (2014). "Labor Market Discrimination in Lima, Peru: Evidence from a Field Experiment,” World Development”, 58: 83-94.

Galarza, Francisco, Yamada, Gustavo (2017). "Triple penalty in employment access: the role of beauty, race and sex," Journal of Applied Economics, 20(1): 29-47.

Goldin, Claudia, and Lawrence Katz. (2008) The Race Between Education and Technology. Harvard University Press.

Instituto Nacional de Estadística e Informática-INEI (2019). Perú: Indicadores de educación por departamentos, 2008-2018. Lima: INEI.

Imbens, G. W., \& Rubin, D. B. (2015). Causal inference in statistics, social, and biomedical sciences. Cambridge University Press.

Laajaj, Rachid, Moya, Andrés, Sánchez, Fabio (2018). "Equality of Opportunity and Human Capital Accumulation: Motivational Effect of a Nationwide Scholarship in Colombia," Documento CEDE 26.

Lahey, Joanna N., Beasley, Ryan A. (2009). “Computerized Audit Studies,” Journal of Economic Behavior and Organization, 70: 508-514. 
Lahey, Joanna N., Beasley, Ryan A. (2018). Technical aspects of correspondence studies. In Gaddis, S.M., editor, Audit studies: Behind the scenes with theory, method, and nuance (pp. 81-101). Springer.

Londoño-Velez, Juliana, Rodríguez, Catherine, Sánchez, Fabio (2020). "Upstream and Downstream Impacts of College Merit-Based Financial Aid for Low-Income Students: Ser Pilo Paga in Colombia,” American Economic Journal: Economic Policy, 12(2): 193-227.

Neumark, David (2018). "Experimental Research on Labor Market Discrimination,” Journal of Economic Literature, 56(3): 799-866.

Patrinos, Harry Anthony, and George Psacharopoulos (2020). "Returns to education in developing countries.” In The Economics of Education, pp. 53-64. Academic Press.

Solis, Alex (2017). “Credit Access and College Enrollment.” Journal of Political Economy 125 (2): 562-622.

Superintendencia Nacional de Educación Superior Universitaria-SUNEDU (2018). Informe bienal sobre la realidad universitaria peruana. Lima.

https://andina.pe/agencia/noticia-conoce-aqui-ranking-universidades-mas-publicaciones-tras-su-licenciamiento-809655.aspx

UNESCO (2020) Global education monitoring report, 2020: Inclusion and education: all means all. Geneva.

Young, A., (2019). "Channeling fisher: Randomization tests and the statistical insignificance of seemingly significant experimental results," The Quarterly Journal of Economics, 134(2): 557-598. 
Appendix Figure 1: Beca 18 Selection Process ${ }^{a}$

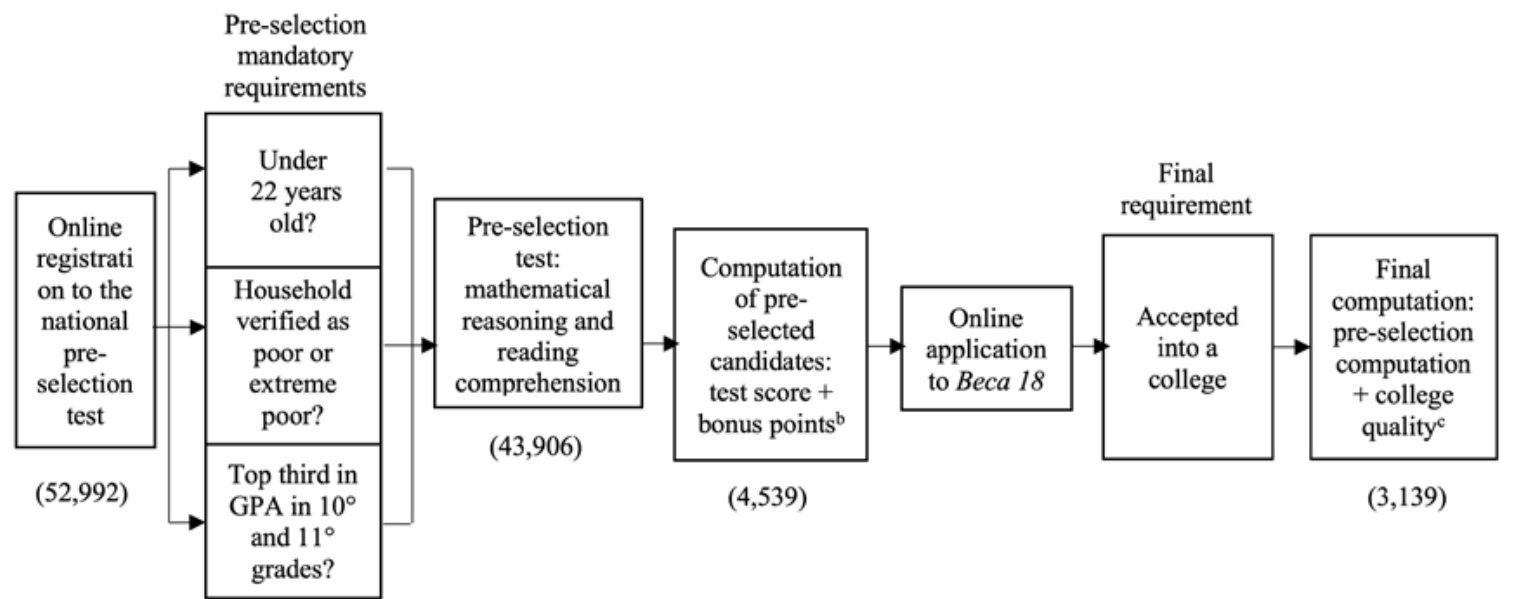

$(51,480)$

Source: Technical Dossier of the 2020 Call for Beca 18, PRONABEC (2020).

Notes:

a Mostly based on the 2019 scholarship call. Numbers within parenthesis are the students total in each stage of the process.

b Additional points are given to applicants in priority situations (disability, active fireperson or children of fireperson, volunteers registered by the Ministry of Women and Vulnerable Populations or indigenous or afro-descendant population).

c The quality of the colleges and careers chosen by applicants is considered in the final allocation of scholarships. Quality indicators must be reliable and from and external source. For 5-year colleges, these indicators include, research (publications), teaching (degrees attained by faculty, and student/teacher ratio), graduates wages, acceptance rate, and students' perception about the services received, teaching, infrastructure and college reputation, while for 3-year colleges, includes, teaching (degrees and student/teacher ratio), graduates wages, acceptance rate, college physical infrastructure, Personal computer/student ratio, and share of graduates with a bachelor's degree (Licenciate). 
Appendix Table 2: Occupations used

\begin{tabular}{|c|c|c|c|}
\hline Occupation & $\mathbf{N}$ & Share (\%) & Callback (\%) \\
\hline Accountant & 56 & 1.6 & 3.57 \\
\hline Accounting Assistant & 536 & 15.1 & 6.53 \\
\hline Business Administration Assistant & 388 & 10.9 & 4.38 \\
\hline Business Administration/Management & 228 & 6.4 & 4.39 \\
\hline Civil Engineering & 102 & 2.9 & 3.92 \\
\hline Engineering (Others) ${ }^{1 /}$ & 238 & 6.7 & 15.13 \\
\hline Cooking & 152 & 4.3 & 9.87 \\
\hline Cooking Assistant & 112 & 3.2 & 18.75 \\
\hline Dental Assistant & 80 & 2.3 & 5.00 \\
\hline Graphical/Fashion/Design & 164 & 4.6 & 12.80 \\
\hline Lawyer & 136 & 3.8 & 13.24 \\
\hline Logistics & 56 & 1.6 & 12.50 \\
\hline Marketing & 48 & 1.4 & 16.67 \\
\hline Nursing Assistant & 60 & 1.7 & 10.00 \\
\hline Pharmaceutical Chemist & 40 & 1.1 & 17.50 \\
\hline Physician/Nurse & 144 & 4.1 & 24.31 \\
\hline Sales Representative & 220 & 6.2 & 18.18 \\
\hline Secretary & 136 & 3.8 & 8.09 \\
\hline Teacher (Primary and Secondary Education) & 172 & 4.8 & 7.56 \\
\hline Technician in Mechanics & 96 & 2.7 & 10.42 \\
\hline Technician in Electricity/Mechanics/Electronics & 308 & 8.7 & 12.34 \\
\hline Others $^{2 /}$ & 76 & 2.1 & 11.84 \\
\hline Technical Occupations & 1903 & 53.6 & 9.25 \\
\hline Professional Occupations & 1645 & 46.4 & 11.61 \\
\hline Total & 3548 & 100.0 & 10.34 \\
\hline
\end{tabular}

1/ Includes Agrarian, Chemical, Electric, Electronic, Environmental, Food, Forestry, Industrial, Planning, and Telecommunications Engineering.

2/ Includes Sociologist, Touristic Guide, Community Manager, Architect, Seamstress 
Appendix 3: Sample resumes sent for a graphical design (diseño gráfico) job

\section{Darwin Nelson Cusiquispe Uchuypoma}

cusiquispe.uchuypoma.darwin10@outlook.com

Cl Muquiyauyos Nro 147, Rímac

× 993.144 .907

Tengo capacidad para trabajar en equipo, buena predisposición para asumir nuevos retos, rápida adaptación y sólidos valores personales, participando proactivamente en las labores que se encuentren bajo mi responsabilidad. Los cuales me permitan desarrollarme personal y profesionalmente.

\section{Estudios Realizados}

$2013-2015$

Cibertec

Profesional en Diseño Gráfico

$2008-2012$

Pedro A. Labarthe

La Victoria

\section{Trabajos Realizados}

2017 - actualmente

$2016-2017$
Consorcio Carolina

Diseño Gráfico

Desarrollo de diversas piezas gráficas para los restaurantes Texas y Delibakery.

Approach BTL

Diseño Gráfico - Practicante

Crear y desarrollar ideas en textos creativos para el área de diseño y para el cliente final.

\section{Otros}

Computación

Idioma extranjero
Microsoft Office: Word (avanzado), Excel (avanzado), Power Point (avanzado) y Outlook. Adobe Photoshop, Corel, Illustrator 3D, InDesign.

Inglés (avanzado). 


\section{Jairo Giancarlo Diaz Quinteros}

diaz.quinteros.jairo10@outlook.com

JR Raul Porras Barrenechea 125, Lince

Teléfono: 992919542

Persona responsable, creativa, con iniciativa y puntualidad, asumo con agrado los retos y metas que las organizaciones me pudieran plantear; con buen manejo de relaciones interpersonales, facilidad para trabajar en equipo, en condiciones de alta presioón, así como para resolver problemas eficientemente y lograr las metas trazadas por la empresa y mi grupo de trabajo.

\section{Formación académica}

$2013-2015$

$2008-2012$

\section{Experiencias}

2017 - actualmente

$2016-2017$
Nobert Wiener

Profesional en Diseño Gráfico

Premios: Beca18 (PRONABEC)

Miguel Grau

Magdalena

Consorcio Carolina

Diseño Gráfico

Desarrollo de diversas piezas gráficas para los restaurantes Texas y Delibakery.

Fine Card

Practicante de Diseño Gráfico

Realicé diseño para los diversos clientes. Tenía a mi cargo el área de ventas y recepción de los diversos pedidos.

\section{Otros}

Idiomas

Inglés (avanzado)

Programas

Microsoft Office (avanzado),Illustrator 3D, Corel, InDesign y Adobe Photoshop. 


\section{Augusto Mari Hurtado Charccahuana \\ hurtado.charccahuana.augusto10@hotmail.com JR Echenique 1853 Ur San Gregorio, Independencia \\ 987127123}

Soy una persona con capacidades orientadas al cumplimiento de los objetivos, optimista, proactiva, con facilidad para el trabajo en equipo, adaptable a los cambios y comunicación efectiva.

\section{Educación}

\begin{tabular}{|c|c|}
\hline $2013-2015$ & $\begin{array}{l}\text { Toulouse Lautrec } \\
\text { Profesional en Diseño Gráfico } \\
\text { Beneficiario del Programa Nacional de Beca18 - } \\
\text { PRONABEC }\end{array}$ \\
\hline \multirow[t]{2}{*}{$2008-2012$} & I.E.P.S.M. $\mathrm{N}^{\circ} 16458$ Juan Velasco Alvarado \\
\hline & Experiencia Laboral \\
\hline 2017 - actualmente & $\begin{array}{l}\text { Lapiceros y Publicidad } \\
\text { Diseño Gráfico } \\
\text { Elaboración y modificación de logos y tex- } \\
\text { tos para luego ser llevados a grabados con la } \\
\text { máquina Láser, grabado en lapiceros, placas de } \\
\text { metal, entre otros. }\end{array}$ \\
\hline \multirow[t]{2}{*}{$2016-2017$} & $\begin{array}{l}\text { Pan de La Chola } \\
\text { Diseño Gráfico: Practicante } \\
\text { Asistente de producción y del área de servicio. }\end{array}$ \\
\hline & Otros Conocimientos \\
\hline Computación & $\begin{array}{l}\text { Microsoft Office (nivel avanzado),Adobe Photo- } \\
\text { shop, InDesign, Corel, Illustrator 3D. }\end{array}$ \\
\hline Idiomas & Inglés (nivel avanzado en el Británico, 2017). \\
\hline
\end{tabular}




\section{Adela Daniela Yurivilca Chavarry \\ yurivilca.chavarry.adela10@gmail.com \\ Jirón Juan Pablo Fernandini 1485, San Juan de Miraflores \\ Cel: $993-486-591$}

Soy una persona con un alto sentido de responsabilidad, creativa, pro-activa y con vocación de servicio. Con habilidad para generar compromisos con los demás, manejo eficaz de la comunicación, capaz de asumir nuevos retos. Actualmente estoy buscando una empresa donde pueda desarrollarme a nivel profesional y personal con muchos deseos de superación.

\section{Estudios}

\begin{tabular}{|c|c|}
\hline $2013-2015$ & $\begin{array}{l}\text { Cibertec } \\
\text { Profesional en Diseño Gráfico }\end{array}$ \\
\hline $2008-2012$ & $\begin{array}{l}\text { Miguel Grau } \\
\text { Magdalena }\end{array}$ \\
\hline
\end{tabular}

\section{Historia Laboral}

2017 - actualmente

Acosta Stock

Diseño Gráfico

Trabajo con Gravograf (Pantografia), realización de volantes y tripticos. Grabado en joyeria y llaveros.

$2016-2017$

Approach BTL Diseño Gráfico - Practicante Crear y desarrollar ideas en textos creativos para el área de diseño y para el cliente final.

\section{Información Adicional}

Otros idiomas

Computación e Informática
Inglés: avanzado.

MS Office: avanzado. Adobe Photoshop, InDesign, Corel, Illustrator 3D. 
Appendix Table 4. Balance test

Beca 18

\begin{tabular}{|c|c|c|c|c|}
\hline & Yes & No & Difference & p-value \\
\hline male or female applicant & 0.500 & 0.504 & 0.004 & 0.78307 \\
\hline eth_1 & 0.251 & 0.249 & -0.003 & 0.83216 \\
\hline eth_2 & 0.250 & 0.250 & 0.000 & 1.00000 \\
\hline eth_3 & 0.251 & 0.249 & -0.003 & 0.83216 \\
\hline eth_4 & 0.247 & 0.253 & 0.006 & 0.67165 \\
\hline title_style_1 & 0.333 & 0.348 & 0.015 & 0.31703 \\
\hline title_style_2 & 0.338 & 0.321 & -0.017 & 0.22849 \\
\hline title_style_3 & 0.329 & 0.331 & 0.003 & 0.84527 \\
\hline phone_format_1 & 0.255 & 0.245 & -0.009 & 0.47989 \\
\hline phone_format_2 & 0.238 & 0.262 & $0.023^{*}$ & 0.07732 \\
\hline phone_format_3 & 0.255 & 0.245 & -0.010 & 0.43708 \\
\hline phone_format_4 & 0.252 & 0.248 & -0.004 & 0.77750 \\
\hline phone_number_1 & 0.259 & 0.241 & -0.019 & 0.15763 \\
\hline phone_number_2 & 0.251 & 0.249 & -0.003 & 0.83216 \\
\hline phone_number_3 & 0.239 & 0.261 & 0.022 & 0.10414 \\
\hline phone_number_4 & 0.250 & 0.250 & 0.000 & 1.00000 \\
\hline email_1 & 0.251 & 0.249 & -0.003 & 0.83216 \\
\hline email_2 & 0.250 & 0.250 & 0.000 & 1.00000 \\
\hline email_3 & 0.251 & 0.249 & -0.003 & 0.83216 \\
\hline email_4 & 0.247 & 0.253 & 0.006 & 0.67165 \\
\hline fonts_1 & 0.257 & 0.243 & -0.014 & 0.28926 \\
\hline fonts_2 & 0.237 & 0.263 & $0.026^{* *}$ & 0.04787 \\
\hline fonts_3 & 0.254 & 0.246 & -0.007 & 0.57195 \\
\hline fonts_4 & 0.252 & 0.248 & -0.005 & 0.72391 \\
\hline objective_1 & 0.082 & 0.098 & $0.015^{*}$ & 0.07791 \\
\hline objective_2 & 0.097 & 0.087 & -0.010 & 0.24374 \\
\hline objective_3 & 0.096 & 0.083 & -0.013 & 0.14825 \\
\hline objective_4 & 0.096 & 0.088 & -0.007 & 0.39658 \\
\hline objective_5 & 0.087 & 0.089 & 0.002 & 0.82903 \\
\hline objective_6 & 0.095 & 0.088 & -0.007 & 0.39549 \\
\hline objective_7 & 0.098 & 0.095 & -0.003 & 0.75589 \\
\hline objective_8 & 0.089 & 0.094 & 0.005 & 0.59623 \\
\hline objective_9 & 0.078 & 0.098 & $0.020^{* *}$ & 0.02038 \\
\hline objective_10 & 0.089 & 0.089 & 0.000 & 0.95720 \\
\hline objective_11 & 0.093 & 0.091 & -0.002 & 0.83216 \\
\hline edu_style_1 & 0.251 & 0.249 & -0.002 & 0.88764 \\
\hline edu_style_2 & 0.243 & 0.257 & 0.013 & 0.32261 \\
\hline edu_style_3 & 0.248 & 0.252 & 0.005 & 0.72391 \\
\hline edu_style_4 & 0.258 & 0.242 & -0.016 & 0.22972 \\
\hline edu_edit_1 & 0.203 & 0.192 & -0.011 & 0.37671 \\
\hline edu_edit_2 & 0.196 & 0.202 & 0.006 & 0.61828 \\
\hline edu_edit_3 & 0.190 & 0.210 & $0.020^{*}$ & 0.09986 \\
\hline edu_edit_4 & 0.210 & 0.196 & -0.014 & 0.27006 \\
\hline edu_edit_5 & 0.202 & 0.200 & -0.002 & 0.87873 \\
\hline work_style_1 & 0.253 & 0.247 & -0.006 & 0.67165 \\
\hline work_style_2 & 0.246 & 0.254 & 0.008 & 0.52489 \\
\hline work_style_3 & 0.262 & 0.238 & $-0.023^{*}$ & 0.07732 \\
\hline work_style_4 & 0.240 & 0.260 & 0.021 & 0.12008 \\
\hline
\end{tabular}




\begin{tabular}{l} 
work_edit_1 \\
work_edit_2 \\
work_edit_3 \\
work_edit_4 \\
work_edit_5 \\
jobs_worked_1 \\
jobs_worked_2 \\
jobs_worked_3 \\
jobs_worked_4 \\
jobs_worked_5 \\
jobs_worked_6 \\
jobs_worked_7 \\
jobs_worked_8 \\
jobs_worked_9 \\
jobs_worked_10 \\
jobs_worked_11 \\
jobs_worked_12 \\
jobs_worked_13 \\
jobs_worked_14 \\
jobs_worked_15 \\
jobs_worked_16 \\
jobs_worked_17 \\
jobs_worked_18 \\
jobs_worked_19 \\
jobs_worked_20 \\
jobs_worked2_1 \\
jobs_worked2_2 \\
jobs_worked2_3 \\
jobs_worked2_4 \\
jobs_worked2_5 \\
jobs_worked2_6 \\
jobs_worked2_7 \\
jobs_worked2_8 \\
jobs_worked2_9 \\
jobs_worked2_10 \\
jobs_worked2_11 \\
jobs_worked2_12 \\
jobs_worked2_13 \\
jobs_worked2_14 \\
job_title_1 \\
job_title_2 \\
job_title_3 \\
job_title_4 \\
job_title_5 \\
job_title_6 \\
job_title_7 \\
job_title_8 \\
job_title_9 \\
job_title_10 \\
job_title_11 \\
job_title_12 \\
\hline
\end{tabular}


job_title_13

job_title_14

job_title_15

job_title_16

job_title_17

job_title_18

job_title_19

job_title_20

job_title_21

job_title_22

job_title_23

job_title_24

job_title_25

job_title_26

job_title_27

job_title_28

job_title_29

job_title_30

job_title_31

job_title_32

job_title_33

job_title_34

job_title_35

job_title_36

job_title_37

job_title_38

job_title_39

job_title_40

job_title_41

job_title_42

job_title_43

job_title_44

job_title_45

job_title_46

job_title_47

job_title_48

job_title_49

job_title_50

job_title_51

job_title_52

job_title_53

job_title_54

job_title_55

job_title_56

job_title_57

job_title_58

job_title_59

job_title_60

job_title_61

job_title_62

job_title_63

\subsection{4}

0.007

0.006

0.005

0.004

0.101

0.003

0.001

0.160

0.019

0.001

0.001

0.006

0.003

0.007

0.004

0.001

0.001

0.001

0.001

0.002

0.001

0.005

0.007

0.001

0.001

0.002

0.001

0.022

0.001

0.001

0.001

0.033

0.003

0.001

0.020

0.001

0.001

0.001

0.001

0.002

0.001

0.028

0.001

0.003

0.012

0.001

0.025

0.001

0.007

0.027
0.004

0.007

0.006

0.005

0.004

0.101

0.003

0.001

0.160

0.019

0.001

0.001

0.006

0.003

0.007

0.004

0.001

0.001

0.001

0.001

0.002

0.001

0.005

0.007

0.001

0.001

0.002

0.001

0.022

0.001

0.001

0.001

0.033

0.003

0.001

0.020

0.001

0.001

0.001

0.001

0.002

0.001

0.028

0.001

0.003

0.012

0.001

0.025

0.001

0.007

0.027
0.000

1.00000

1.00000

1.00000

1.00000

1.00000

1.00000

1.00000

1.00000

1.00000

1.00000

1.00000

1.00000

1.00000

1.00000

1.00000

1.00000

1.00000

1.00000

1.00000

1.00000

1.00000

1.00000

1.00000

1.00000

1.00000

1.00000

1.00000

1.00000

1.00000

1.00000

1.00000

1.00000

1.00000

1.00000

1.00000

1.00000

1.00000

1.00000

1.00000

1.00000

1.00000

1.00000

1.00000

1.00000

1.00000

1.00000

1.00000

1.00000

1.00000

1.00000

1.00000 


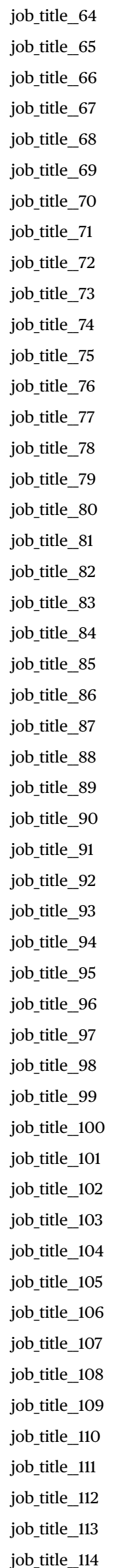




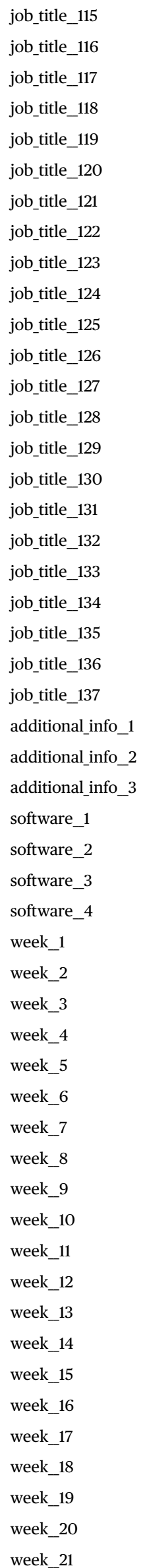




\begin{tabular}{|c|c|c|c|c|}
\hline week_22 & 0.018 & 0.018 & 0.000 & 1.00000 \\
\hline week_23 & 0.024 & 0.024 & 0.000 & 1.00000 \\
\hline week_24 & 0.019 & 0.019 & 0.000 & 1.00000 \\
\hline week_25 & 0.042 & 0.042 & 0.000 & 1.00000 \\
\hline week_26 & 0.037 & 0.037 & 0.000 & 1.00000 \\
\hline week_27 & 0.018 & 0.018 & 0.000 & 1.00000 \\
\hline week_28 & 0.014 & 0.014 & 0.000 & 1.00000 \\
\hline week_29 & 0.020 & 0.020 & 0.000 & 1.00000 \\
\hline week_30 & 0.012 & 0.012 & 0.000 & 1.00000 \\
\hline week_31 & 0.021 & 0.021 & 0.000 & 1.00000 \\
\hline week_32 & 0.029 & 0.029 & 0.000 & 1.00000 \\
\hline hs_name_1 & 0.006 & 0.003 & -0.003 & 0.10757 \\
\hline hs_name_2 & 0.025 & 0.020 & -0.005 & 0.25867 \\
\hline hs_name_3 & 0.044 & 0.052 & 0.008 & 0.19871 \\
\hline hs_name_4 & 0.023 & 0.028 & 0.005 & 0.32985 \\
\hline hs_name_5 & 0.022 & 0.019 & -0.002 & 0.58820 \\
\hline hs_name_6 & 0.024 & 0.024 & -0.000 & 0.92057 \\
\hline hs_name_7 & 0.025 & 0.020 & -0.005 & 0.25867 \\
\hline hs_name_8 & 0.019 & 0.024 & 0.005 & 0.24388 \\
\hline hs_name_9 & 0.050 & 0.053 & 0.003 & 0.62733 \\
\hline hs_name_10 & 0.020 & 0.021 & 0.001 & 0.74528 \\
\hline hs_name_11 & 0.007 & 0.005 & -0.001 & 0.54744 \\
\hline hs_name_12 & 0.047 & 0.049 & 0.002 & 0.77418 \\
\hline hs_name_13 & 0.051 & 0.052 & 0.000 & 0.94494 \\
\hline hs_name_14 & 0.022 & 0.023 & 0.002 & 0.67976 \\
\hline hs_name_15 & 0.028 & 0.018 & $-0.009^{* *}$ & 0.04098 \\
\hline hs_name_16 & 0.022 & 0.027 & 0.006 & 0.23364 \\
\hline hs_name_17 & 0.023 & 0.022 & -0.001 & 0.83810 \\
\hline hs_name_18 & 0.023 & 0.025 & 0.002 & 0.61808 \\
\hline hs_name_19 & 0.019 & 0.021 & 0.001 & 0.74247 \\
\hline hs_name_20 & 0.018 & 0.026 & $0.007^{*}$ & 0.09521 \\
\hline hs_name_21 & 0.026 & 0.028 & 0.002 & 0.70660 \\
\hline hs_name_22 & 0.028 & 0.024 & -0.003 & 0.50093 \\
\hline hs_name_23 & 0.026 & 0.023 & -0.003 & 0.48925 \\
\hline hs_name_24 & 0.002 & 0.004 & 0.002 & 0.24766 \\
\hline hs_name_25 & 0.003 & 0.002 & -0.001 & 0.56326 \\
\hline hs_name_26 & 0.023 & 0.021 & -0.003 & 0.53157 \\
\hline hs_name_27 & 0.027 & 0.021 & -0.006 & 0.22922 \\
\hline hs_name_28 & 0.048 & 0.043 & -0.005 & 0.46256 \\
\hline hs_name_29 & 0.003 & 0.004 & 0.001 & 0.43789 \\
\hline hs_name_30 & 0.048 & 0.036 & $-0.012^{\star *}$ & 0.04771 \\
\hline hs_name_31 & 0.002 & 0.004 & 0.002 & 0.24766 \\
\hline hs_name_32 & 0.005 & 0.005 & 0.000 & 1.00000 \\
\hline hs_name_33 & 0.042 & 0.037 & -0.005 & 0.38532 \\
\hline hs_name_34 & 0.005 & 0.006 & 0.001 & 0.68233 \\
\hline hs_name_35 & 0.044 & 0.057 & $0.013^{*}$ & 0.05057 \\
\hline hs_name_36 & 0.020 & 0.020 & 0.000 & 1.00000 \\
\hline hs_name_37 & 0.003 & 0.005 & 0.002 & 0.22443 \\
\hline hs_name_38 & 0.046 & 0.047 & 0.001 & 0.82764 \\
\hline hs_name_39 & 0.023 & 0.023 & 0.000 & 0.91903 \\
\hline hs_name_40 & 0.051 & 0.052 & 0.001 & 0.83587 \\
\hline
\end{tabular}




\begin{tabular}{|c|c|c|c|c|}
\hline hs_name_41 & 0.004 & 0.001 & $-0.003^{* *}$ & 0.03460 \\
\hline hs_name_42 & 0.005 & 0.003 & -0.001 & 0.46608 \\
\hline hs2_name_1 & 0.050 & 0.052 & 0.002 & 0.72763 \\
\hline hs2_name_2 & 0.010 & 0.009 & -0.000 & 0.87534 \\
\hline hs2_name_3 & 0.052 & 0.051 & -0.001 & 0.88992 \\
\hline hs2_name_4 & 0.024 & 0.025 & 0.001 & 0.84266 \\
\hline hs2_name_5 & 0.024 & 0.023 & -0.000 & 0.91981 \\
\hline hs2_name_6 & 0.010 & 0.010 & 0.000 & 1.00000 \\
\hline hs2_name_7 & 0.010 & 0.008 & -0.002 & 0.42133 \\
\hline hs2_name_8 & 0.008 & 0.011 & 0.003 & 0.27209 \\
\hline hs2_name_9 & 0.042 & 0.047 & 0.005 & 0.41322 \\
\hline hs2_name_10 & 0.026 & 0.020 & -0.007 & 0.15258 \\
\hline hs2_name_11 & 0.056 & 0.051 & -0.004 & 0.54108 \\
\hline hs2_name_12 & 0.046 & 0.051 & 0.005 & 0.47524 \\
\hline hs2_name_13 & 0.044 & 0.040 & -0.005 & 0.44643 \\
\hline hs2_name_14 & 0.021 & 0.026 & 0.005 & 0.26809 \\
\hline hs2_name_15 & 0.020 & 0.029 & $0.009^{\star}$ & 0.06048 \\
\hline hs2_name_16 & 0.011 & 0.012 & 0.001 & 0.66652 \\
\hline hs2_name_17 & 0.008 & 0.011 & 0.003 & 0.35228 \\
\hline hs2_name_18 & 0.022 & 0.018 & -0.004 & 0.32423 \\
\hline hs2_name_19 & 0.008 & 0.005 & -0.003 & 0.25538 \\
\hline hs2_name_20 & 0.022 & 0.020 & -0.001 & 0.74800 \\
\hline hs2_name_21 & 0.026 & 0.023 & -0.002 & 0.62136 \\
\hline hs2_name_22 & 0.013 & 0.008 & -0.005 & 0.13830 \\
\hline hs2_name_23 & 0.008 & 0.008 & 0.000 & 0.86526 \\
\hline hs2_name_24 & 0.008 & 0.012 & 0.004 & 0.21487 \\
\hline hs2_name_25 & 0.045 & 0.037 & -0.008 & 0.18953 \\
\hline hs2_name_26 & 0.025 & 0.028 & 0.003 & 0.56905 \\
\hline hs2_name_27 & 0.028 & 0.021 & -0.007 & 0.13468 \\
\hline hs2_name_28 & 0.046 & 0.055 & 0.008 & 0.20887 \\
\hline hs2_name_29 & 0.046 & 0.044 & -0.002 & 0.76887 \\
\hline hs2_name_30 & 0.021 & 0.010 & $-0.011^{* * *}$ & 0.00404 \\
\hline hs2_name_31 & 0.043 & 0.043 & -0.000 & 0.93979 \\
\hline hs2_name_32 & 0.015 & 0.014 & -0.001 & 0.70344 \\
\hline hs2_name_33 & 0.019 & 0.017 & -0.001 & 0.73016 \\
\hline hs2_name_34 & 0.012 & 0.019 & $0.007^{*}$ & 0.08247 \\
\hline hs2_name_35 & 0.023 & 0.025 & 0.001 & 0.76483 \\
\hline hs2_name_36 & 0.018 & 0.020 & 0.002 & 0.65175 \\
\hline hs2_name_37 & 0.013 & 0.019 & 0.006 & 0.11467 \\
\hline hs2_name_38 & 0.021 & 0.027 & 0.006 & 0.19058 \\
\hline hs2_name_39 & 0.016 & 0.023 & 0.007 & 0.12295 \\
\hline hs2_name_40 & 0.021 & 0.014 & -0.007 & 0.10069 \\
\hline hs2_name_41 & 0.020 & 0.014 & -0.006 & 0.11981 \\
\hline DistritoResidencia_1 & 0.046 & 0.048 & 0.002 & 0.77315 \\
\hline DistritoResidencia_2 & 0.034 & 0.027 & -0.007 & 0.21249 \\
\hline DistritoResidencia_3 & 0.056 & 0.052 & -0.004 & 0.58771 \\
\hline DistritoResidencia_4 & 0.015 & 0.017 & 0.002 & 0.54406 \\
\hline DistritoResidencia_5 & 0.024 & 0.021 & -0.003 & 0.53578 \\
\hline DistritoResidencia_6 & 0.076 & 0.063 & -0.013 & 0.10439 \\
\hline DistritoResidencia_7 & 0.074 & 0.071 & -0.004 & 0.63716 \\
\hline DistritoResidencia_8 & 0.050 & 0.045 & -0.005 & 0.47319 \\
\hline
\end{tabular}


DistritoResidencia_9

DistritoResidencia_10

DistritoResidencia_11

DistritoResidencia_12

DistritoResidencia_13

DistritoResidencia_14

DistritoResidencia_15

DistritoResidencia_16

DistritoResidencia_17

DistritoResidencia_18

DistritoResidencia_19

DistritoResidencia_20

DistritoResidencia_21

DistritoResidencia_22
0.081

0.057

0.049

0.021

0.054

0.049

0.022

0.024

0.035

0.040

0.040

0.032

0.029

0.093
0.074

0.046

0.052

0.026

0.050

0.055

0.030

0.027

0.035

0.048

0.048

0.031

0.031

0.102
$-0.007$

0.39079

0.11062

0.62583

0.22473

0.58143

0.40826

0.12556

0.55880

1.00000

0.20371

0.17946

0.86069

0.65495

0.32746

0.009 
Appendix Table 5. Regression with clusters at the job ad level

\begin{tabular}{|c|c|c|c|c|c|}
\hline & (1) & (2) & (3) & (4) & (5) \\
\hline \multirow[t]{2}{*}{ Beca 18} & $0.019^{* * *}$ & $0.019^{* *}$ & $0.018^{* *}$ & $0.018^{* *}$ & $0.019^{* * *}$ \\
\hline & $(0.007)$ & $(0.007)$ & $(0.007)$ & $(0.007)$ & $(0.007)$ \\
\hline Randomized Inference: p-value & {$[0.072]$} & [0.068] & {$[0.078]$} & {$[0.074]$} & [0.071] \\
\hline Candidate controls & No & Yes & Yes & Yes & Yes \\
\hline Job controls & No & No & Yes & Yes & Yes \\
\hline Week fixed effects & No & No & No & Yes & Yes \\
\hline Resume. controls & No & No & No & No & Yes \\
\hline Adjusted R2 & 0.001 & 0.007 & 0.009 & 0.043 & 0.039 \\
\hline Mean control & 0.094 & 0.094 & 0.094 & 0.094 & 0.094 \\
\hline Number of clusters & 887 & 887 & 887 & 887 & 887 \\
\hline $\mathrm{N}$ & 3548 & 3548 & 3548 & 3548 & 3548 \\
\hline
\end{tabular}

Robust standard errors (in brackets) are clustered at the job ad level.

${ }^{*} \mathrm{p}<0.10$, ** $\mathrm{p}<0.05,{ }^{* * *} \mathrm{p}<0.01$. 
Appendix Table 9. Effects by college type and poverty level of district of residence

\begin{tabular}{|c|c|c|c|c|c|}
\hline & \multirow{2}{*}{ All } & \multicolumn{2}{|c|}{ 3-year college } & \multicolumn{2}{|c|}{ 5-year college } \\
\hline & & Poor district & Affluent district & Poor district & Affluent district \\
\hline \multirow[t]{2}{*}{ Beca 18} & $0.019^{* *}$ & $0.042^{* * *}$ & 0.027 & 0.010 & 0.001 \\
\hline & $(0.007)$ & $(0.014)$ & $(0.036)$ & $(0.014)$ & $(0.027)$ \\
\hline Randomized Inference: p-value & {$[0.016]$} & [0.000] & {$[0.370]$} & [0.511] & [0.960] \\
\hline Adjusted $\mathrm{R}^{2}$ & 0.486 & 0.439 & 0.248 & 0.588 & 0.611 \\
\hline Mean control & 0.094 & 0.071 & 0.092 & 0.102 & 0.133 \\
\hline $\mathrm{N}$ & 3548 & 1253 & 650 & 1067 & 578 \\
\hline
\end{tabular}

Note: All specifications include a constant term and job ad fixed effects.

Robust standard errors (in parenthesis) are clustered at the resume level. P-values using randomized inference (with 1000 repetitions) in square brackets.

${ }^{*} \mathrm{p}<0.10,{ }^{* *} \mathrm{p}<0.05,{ }^{* * *} \mathrm{p}<0.01$ 
Appendix Table 10: Returns to Beca 18 by gender

\begin{tabular}{|c|c|c|c|}
\hline & (1) & (2) & (3) \\
\hline & All & 3-year college & 5-year college \\
\hline \multirow[t]{2}{*}{ Beca 18} & $0.023^{* *}$ & $0.027^{*}$ & 0.015 \\
\hline & $(0.010)$ & (0.014) & $(0.015)$ \\
\hline \multirow[t]{2}{*}{ Woman } & $0.031^{* * *}$ & $0.030^{*}$ & 0.026 \\
\hline & $(0.012)$ & $(0.016)$ & $(0.017)$ \\
\hline \multirow[t]{2}{*}{ Beca $18^{*}$ Woman } & -0.008 & 0.008 & -0.016 \\
\hline & $(0.017)$ & $(0.023)$ & $(0.024)$ \\
\hline Regular controls & Yes & Yes & Yes \\
\hline Adjusted R2 & 0.485 & 0.410 & 0.560 \\
\hline Mean control (callback for Beca 18 non-recipients) & 0.094 & 0.079 & 0.112 \\
\hline $\mathrm{N}$ & 3548 & 1903 & 1645 \\
\hline
\end{tabular}

Note: All specifications include a constant term and job ad fixed effects.

Robust standard errors (in parenthesis) are clustered at the resume level.

${ }^{*} \mathrm{p}<0.10,{ }^{* *} \mathrm{p}<0.05,{ }^{* * *} \mathrm{p}<0.01$ 